\title{
BOTTOM UP APPROACH: KANCIL, THE STRIVE OF LOCAL INFORMAL COMMUNITIES
}

\author{
DANIEL MAMBO TAMPI ${ }^{1}$, WIDYAWATI SUMADIO ${ }^{1}$, JACHRIZAL SUMABRATA $^{1}$, \\ JOE ANGGIAT ${ }^{2} \&$ ESTY SUYANTI ${ }^{2}$ \\ ${ }^{1}$ Urban Studies: School of Strategic and Global Studies, University of Indonesia, Indonesia \\ ${ }^{2}$ Center For Urban and Region Research, University of Indonesia, Indonesia
}

\begin{abstract}
People with low capacity are vulnerable to flood impact. One community that is prone to flood impacts is those who live on the bank of Ciliwung River in Depok City, Indonesia. In facing floods impact, local people developed Komunitas Anak Ciliwung (KANCIL), an informal society. This society aims to increased awareness of the people in order to save the environment, so that the floods impact can be reduced. The purpose of this study was to determine KANCIL achievement in increasing people participation in maintaining their environment. Data collection was completed by in-depth interviews, while analysis was done using triangulation method between interviews results, expert's judgments and previous researches. There are two activities that are often done, cleaning and patrolling the river bank. After two years of running, KANCIL evolves relationships with other communities who care about the river. In the other hand, the number of participants as well as the activities carried by KANCIL has not increased. The study results show that the communities were not ready yet to involved in the activities that planned by KANCIL. There are several factors that influence the success of KANCIL's program. The main factor that is found is the lack of knowledge of the people to the benefits of maintaining the river. Other factors are also influential is the lack of support from formal leaders. This study concluded that the bottom-up activities such as KANCIL, requires knowledge and commitment of participants as means of locomotion. If the local people do not have adequate knowledge, the role of leaders and formal institutions must be strong. Knowledge and support from formal leaders are important to encourage the people in carrying out the program that has been compiled.

Keywords: bottom up approach, participation, informal local society, knowledge, formal leader.
\end{abstract}

\section{INTRODUCTION}

Ci Liwung, or commonly written as Ciliwung is one of the most important river in Tatar Pasundan, West Java, especially because this river passes through Jakarta and often causes annual flood in downstream area. The length of its main river stream is nearly 120 kilometers and consists of 387 square kilometers catchment area (watershed). The river is relatively wide. In the past, small boats were able to sail in its downstream to distribute any commodities. Ci Liwung flows through Kabupaten Bogor, Kota Bogor, Kota Depok, and Jakarta [1].

As one of the largest and longest river in West Java and Jakarta, Ciliwung becomes an important part of the town development where it is flowed through. And public concern related to the environment along Ciliwung has triggered the development of about twenty Ciliwung Observer Community. To mention some of those areKomunitas Ciliwung Civil Society, Komunitas Ciliwung Bojong gede, Komunitas Ciliwung Depok, Komunitas Ciliwung Condet, Komunitas Sanggar Ciliwung, Komunitas Tree Grower Community (TGC), Komunitas Teens Go Green, etc. [2].

Community is a small unit of social life. Its members know each other, have their own culture that is different from other community culture, and living in an area which is not clearly defined its borders. The result of preliminary observations in Depok found that there is a community called Komunitas Anak Ciliwung (KANCIL), which is formed in 2014. 
This community was established from the initiative of local people who have awareness that there is still some bad behaviours practiced by people living in Ciliwung bank. The kind of these bad behaviours include throwing any trash to the river and the ignorance of young people in Pondok Cina about this phenomenon. So, those trashes keep increasing day by day. The urge is the vision to arouse public awareness in river bank and keep Ciliwung clean to avoid flood. KANCIL is the kind of territorial community (geographical community) which rises from environmental togetherness and tied-place interaction [3].

This study aims to find out KANCIL activities to increase people participation and typology in taking care their environment. A community normally appears in urban areas and has common goals. KANCIL aims to increase public awareness toward Pondok Cina environment in order to reduce flood impact.

Based on the previous research results, entitled "Pengabaian Pemerintah Terhadap Eksistensi Penduduk Pinggir Sungai Ciliwung: Wajah Pengelolaan Sungai di Indonesia” [4], it is concluded that the government has no comprehensive concept in managing river because they focus on physical development. This could be observed as the government excludes people who live along the river and have a direct urgency and dependence on it. This situation underlies my thoughts on how far is the society role toward a disaster, is that community can reduce the impact of a disaster, and how far community can reach their goals.

\section{MATERIALS AND METHODS}

\subsection{The characteristic of research area}

Depok is a city which is populated of 2.033 .508 people. Depok has tropical climate and the rainfalls difference is quite small. This city is also influenced by seasonal weather [5]. Komunitas Anak Ciliwung (KANCIL) is located in the southern Depok at Jalan Kapuk, Kelurahan Pondok Cina, Kecamatan Beji, Depok, West Java.

Flood and inundation is defined as two different things but actually related to each other. Flood is the overflow water that exceeds river capacity in that flume. It is usually preceded by high rainfall or high flow from upstream area. Puddle or inundation flood is water puddle from heavy rainfall accumulation that inundates an area with poor drainage or high-water absorption retention into the soil. Flood and inundation problem are caused by heavy rainfall, modified or disrupted river morphology conditions, poor drainage systems, and other external factors such as high river sedimentation and landslide. This condition is worsened by reduction water carrying capacity in river due to the construction of river bank and river bluff erosion. Later on, this situation can trigger landslide.

Based on the interview, flood in that area is caused by river flow which is coming from upstream (Bogor) to downstream (Depok) and it passes through Pondok Cina. Flood inundation can be occurred for about $2-3$ hours which will cause a dirty environment because it is dominated by trashes. Those trashes are the waste products people throw to the river.

\subsection{Types of public participation}

Sherry Arnstein (Bizjak [6]), divides participation in eight stair steps which are grouped into three typologies consist of citizen power, tokenism, and non-participation. It can be seen in the following picture and table for further information.

Citizen control and full participation are in the same level, which society can participate inside and control the entire process of decision-making. Tokenism level only provides limited opportunities to the society to be involved in the planning process. This participation 
is the same as public participation or pseudo participation; people are not really empowered to be involved in decision-making process. At the level of non-participation, holder of power justifies a proposal as if involve the community [7].

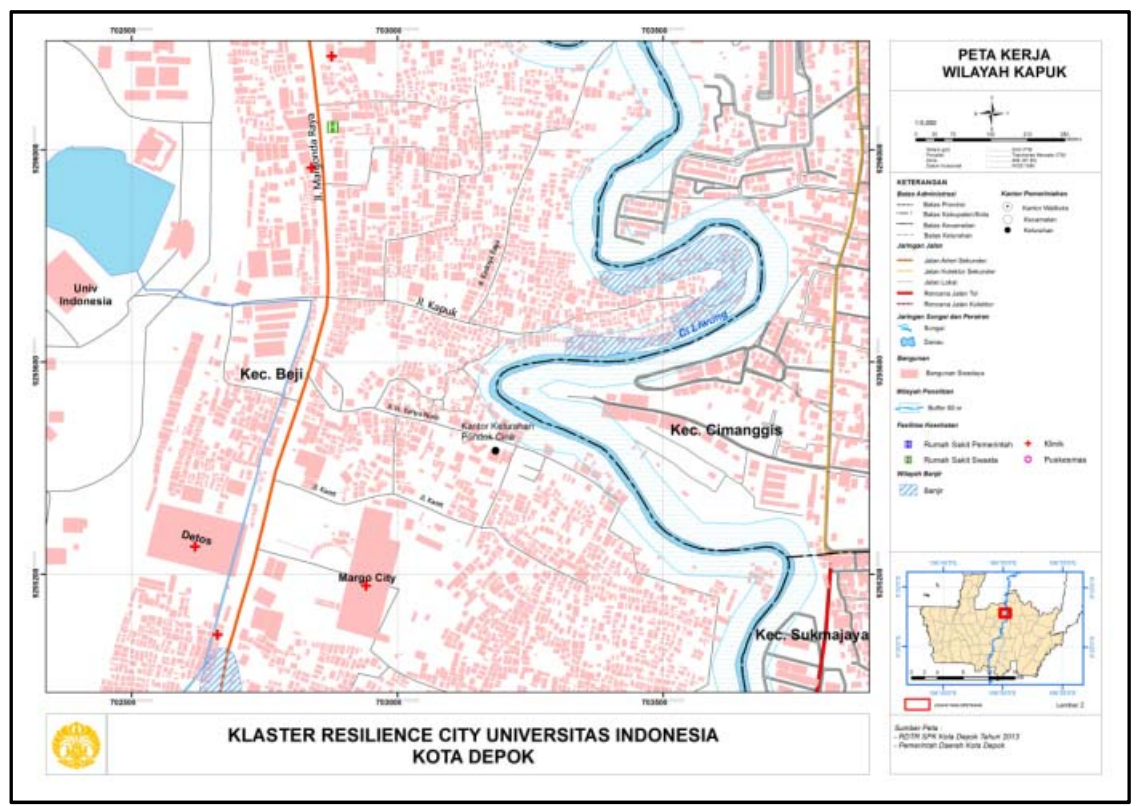

Figure 1: The map of area which is affected by flood in Pondok Cina. (Source: Resilience City Cluster Research Report.)

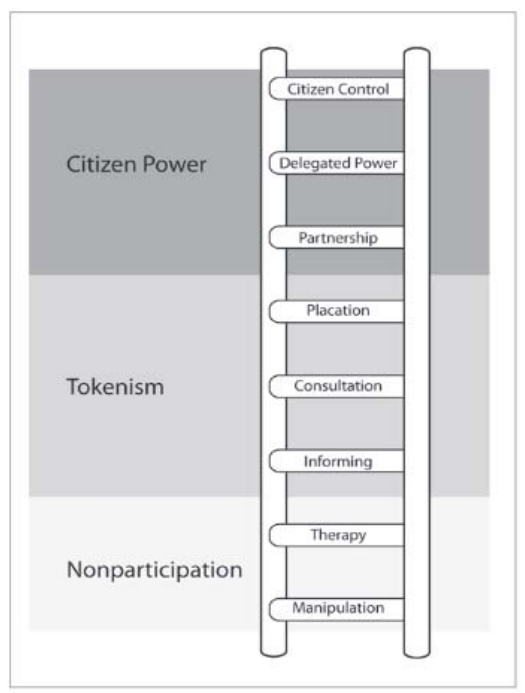

Figure 2: Participation Level According to Sherry Arnstein (Bizjak [6]). (Source: Bizjak, I (2012).) 
Table 1: Levels of Participation According to Sherry Arnstein (Bizjak [6]). (Source: Darminto, 2003 and Aspac Mitra Consultindo, 2005 in Safrida, 2007.)

\begin{tabular}{|c|c|c|}
\hline $\begin{array}{l}\text { Tipologi } \\
\text { Masyarakat }\end{array}$ & $\begin{array}{l}\text { Tingkat } \\
\text { Partisipasi }\end{array}$ & Uraian \\
\hline \multirow[t]{3}{*}{$\begin{array}{l}\text { Degrees of } \\
\text { Citizen Power }\end{array}$} & Citizen Control & $\begin{array}{l}\text { Societies have power over public } \\
\text { policy, both in the formulation, } \\
\text { implementation, evaluation, and } \\
\text { control. }\end{array}$ \\
\hline & Delegated Power & $\begin{array}{l}\text { The government distributes most of } \\
\text { its authority to take care of some } \\
\text { needs. }\end{array}$ \\
\hline & Partnership & $\begin{array}{l}\text { Societies and governments become } \\
\text { equal partner. }\end{array}$ \\
\hline \multirow[t]{3}{*}{$\begin{array}{l}\text { Degree of } \\
\text { Tokenism }\end{array}$} & Placation & $\begin{array}{l}\text { There have been dialogues and } \\
\text { negotiations, but the power to decide } \\
\text { in government level. }\end{array}$ \\
\hline & Consultation & $\begin{array}{l}\text { There is bidirectional } \\
\text { communication such as public } \\
\text { hearing. }\end{array}$ \\
\hline & Informing & $\begin{array}{l}\text { There is improvement but still one- } \\
\text { way communication. }\end{array}$ \\
\hline \multirow[t]{2}{*}{ Non-participation } & Therapy & $\begin{array}{l}\text { Communication is limited and } \\
\text { directives. }\end{array}$ \\
\hline & Manipulation & $\begin{array}{l}\text { There is no communications and } \\
\text { dialogues. }\end{array}$ \\
\hline
\end{tabular}

\subsection{Methodology}

According to William Wiersma (Bachri [8]), "Triangulation is qualitative cross-validation. It assesses the sufficency of the data according to the convergence of multiple data source or multiple data collection procedures". There are three types of triangulation. It consists of Source, Time, Theory, Researcher, and Methodology of Triangulation. The triangulation type that we use is Source Triangulation. It means we compared/rechecked how reliable the information that has been obtained through different sources. For example, compared observation results with interviews; compared between what was said in public and in private, compared interview results with the real documents. The analysis was done based on observation results, comprehensive interviews, assessment from experts, data documentations, and other supporting data such as maps and historical formation of KANCIL.

\section{RESULT AND DISCUSSION}

Community can be used as an identity reference when faced with other communities. Members of the community have a high degree of solidarity [9]. KANCIL is a community formed by people mutual awareness about the importance of protecting the environment such as flood that happened in river bank. Participation was appeared on the initiative young people who have willingness to reduce the impact of flood and clean up the environment together. But the lack of society participation in river bank is shown by still many people throw garbage to the river.

The community members consist of natives who live around Gang Kapuk, Pondok Cina (Gg.Kapuk, Pondok Cina is dominated by newcomers now (boarding house/rent house) 
compared to natives). The membership is voluntary, and no special requirements needed to be the member. The active members are 15 persons now. Before KANCIL community was formed, there were some communities that has been formed such as FKH (Forum Komunitas Hijau) dan KCD (Komunitas Ciliwung Depok). Here is the structure chart, membership, and types of KANCIL activities.

The administrator of this community consists of a Chairman, Vice Chairman, Secretary, Treasurer and several sections include Public Relations Division and Section Skills. Total members are 30 people, while 15 people are the active members, the rest are temporary (if there are certain activities only). KANCIL programs include cleaning and maintaining activities along the Ciliwung by boat (every week), socializing to people (door to door), planting trees on the Ciliwung riverbanks, participating in special events related to Ciliwung and Environment (for example: Annual Event of Ciliwung Day, Exhibitions, etc.). The following are visualization of KANCIL programs (see Fig. 4).

Based on interviews and observations, the area along the river bank in Pondok Cina is vulnerable toward flood. This area is part of Depok which is a connector zone due to its location at the center between Bogor (upstream) and Jakarta (downstream). So many trashes remain in this area. Either comes from upstream or from anyone who lives along the Ciliwung riverbanks. The spirit of togetherness in KANCIL triggers cleaning activities in riverbanks once a week, which is conducted by 15 people. In addition, they also have high solidarity, mutual trust, respect, and support each other. The next focus activity in this paper is maintaining act. This activity utilizes boats to discover and control along the Ciliwung river.

Based on the results of interviews of the members of KANCIL, we know that KANCIL activities cannot be separated from the support of some communities around them such as FKH (Forum Komunitas Hijau) and KCD (Komunitas Ciliwung Depok) that have some same vision for protecting the environment along the river banks to keep it clean. This condition can raise the awareness of society along the Ciliwung riverbank. This picture below shows the location of several Communities that giving attention to the environment along the Ciliwung riverbank.

Fig. 5 shows the three communities that are Community Children Ciliwung (KANCIL), Forum Komunitas Hijau (KFH) and Komunitas Ciliwung Depok (KCD). The distribution of community location shows the division of area along the Ciliwung river, the location of KANCIL is in the northern part of Depok, this community is located in Kelurahan Pondok Cina, on Kampung Kapuk. Meanwhile, the location of the KFH secretariat is in the downtown, in Dinas Badan Lingkungan Hidup (BLH) Depok, while KCD's location is in Grand Depok City, southern part of Depok.
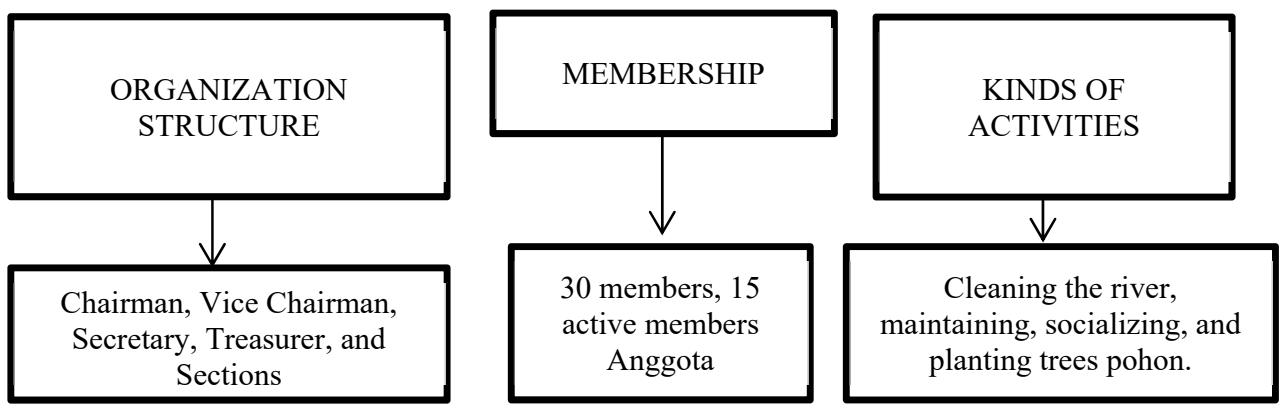

Figure 3: Structure Chart, Membership and Type of KANCIL activities. (Source: Interview Results.) 

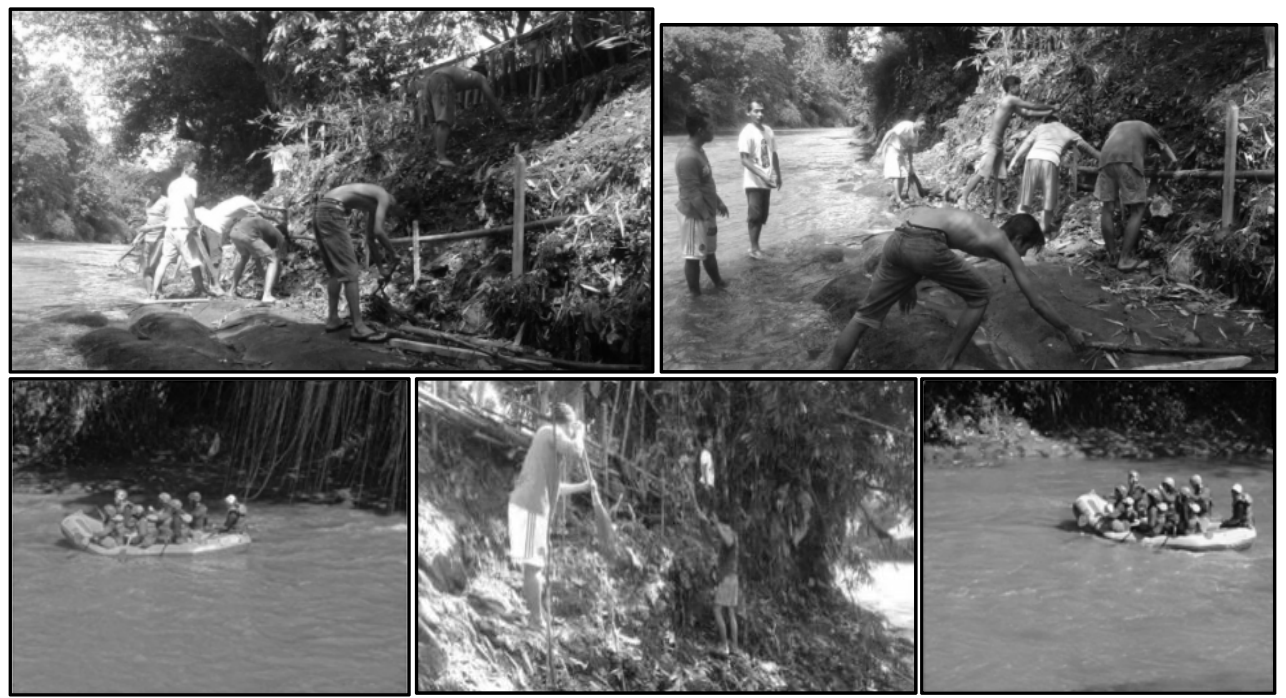

Figure 4: KANCIL activities in the river bank. (Source: KANCIL Documentation.)

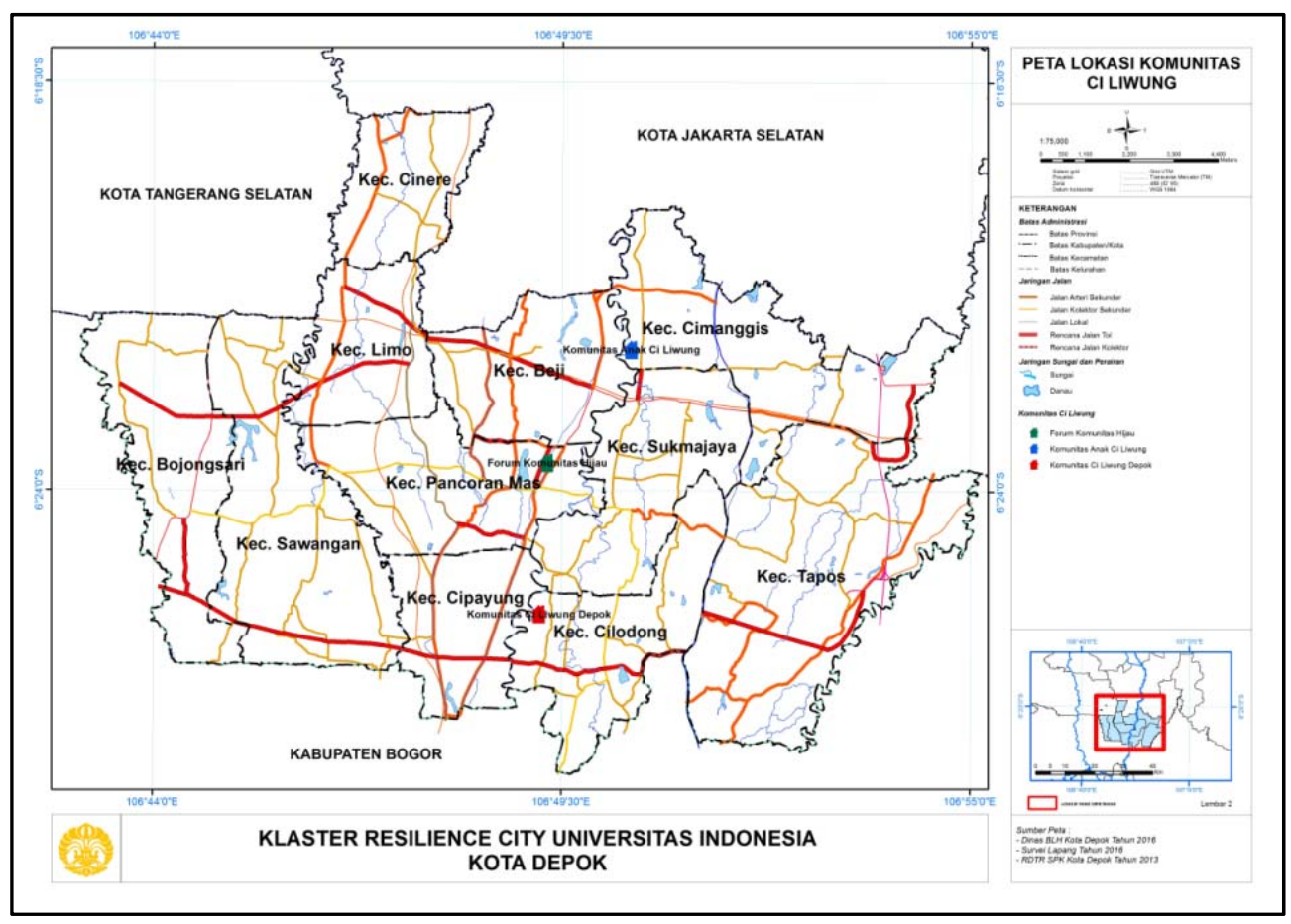

Figure 5: Map Location of KANCIL, FKH, and KCD. (Source: Resilience City Cluster Research Report.) 


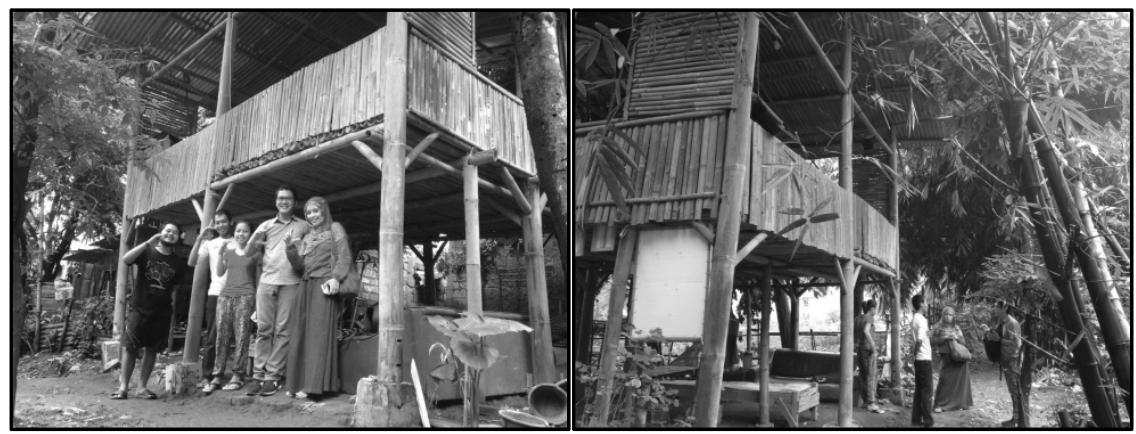

Figure 6: KANCIL basecamp. (Source: Personal Documentation.)

As once said by Mr. Yopie Septiady in his lecture of masyarakat dan kebudayaan perkotaan, a community can be used as a reference for identity. And KANCIL showed their identity as a community which were born and formed by the idea of some youth who are initiatively to maintain 'their area'. It can reduce the impact of flood. KANCIL opens their secretariat or basecamp along the Ciliwung river banks in the form of stilts.

KANCIL has jargon "Salam Ciliwung" and "Salam Lestari". These phrases are ones of spirit identities of KANCIL community in realizing and achieving their visions and missions. But behind the community spirit and high solidarity, there are absolutely obstacles faced by KANCIL such as few people who are involved in this community and many people are not environmentally conscious. Means that from the initial formation of KANCIL, until this time there has not been a significant change.

There is still big amount of trash, less members of KANCIL, and lack of knowledge about river as their adequacy and limitation currently.

These lacks are also marked by the weak of control and government support so that the society should require an active role, but they must face the limitations such as the lack of knowledge on human resources who can make proposals that aim to invoke the fund activities to city government. Currently, KANCIL still utilizes the fund of a joint between the members. They are a little out of scope from Depok City Government reach. That can be seen when I interviewed one of the staff of civil servant in Depok City Government. When I asked, "is there any community to assist the government in flood problems through the river banks?", they just mentioned FKH (Forum Komunitas Hijau) as their partner, where the existence of KANCIL is not known for real. Therefore, KANCIL referred as the community which was informally formed. As a matter of fact, I assume the characteristic of informal community is seen from the limitation resources, having voluntary and having less than 30 members slightly.

That is absolutely the obstacles of government in establishing communication between the community and the government as well as on the contrary. Arnstein (Bizjak [6]) suggested typology of the society and the type of society participation are emphasized in the typology of citizen power as follows:

The table below shows that KANCIL is in typology of Citizen Power, but they are weak in several levels, such as in the Citizen Control of Society. KANCIL has not had the power over public policy, both in the formulation, implementation, evaluation and control, Delegated Power emphasized the government which has not distributed a portion of its 
Table 2: KANCIL typology and type participation.

\begin{tabular}{|l|l|l|}
\hline $\begin{array}{l}\text { Tipologi } \\
\text { Masyarakat } \\
\text { KANCIL }\end{array}$ & $\begin{array}{l}\text { Tingkat } \\
\text { Partisipasi }\end{array}$ & Uraian \\
\hline $\begin{array}{l}\text { Degrees of } \\
\text { Citizen Power }\end{array}$ & Citizen Control & $\begin{array}{l}\text { The society has not had power over } \\
\text { public policy, both in the } \\
\text { formulation, implementation, } \\
\text { evaluation and control. }\end{array}$ \\
\hline & Delegated Power & $\begin{array}{l}\text { The government has not distributed } \\
\text { a portion of its authority to take in } \\
\text { charge some needs. }\end{array}$ \\
\hline & Partnership & $\begin{array}{l}\text { The societies and governments have } \\
\text { not become equal partners yet. }\end{array}$ \\
\hline
\end{tabular}

authority to handle some needs, and Partnership that is the society and the government has not been equal partner.

Thus, the role of government should be very important when KANCIL and the society along the river could be encouraged as the pioneers of environmental awareness through the provision of training and knowledge against the importance of protecting the environment and the river sanitation in order to reduce the impact of floods.

\section{CONCLUSION}

KANCIL (Komunitas Anak Ciliwung) plays an active part of protecting the environment of the Ciliwung river bank. Yet, the lack of concern from Pondok Cina's people toward Ciliwung river banks, the relationship between the community, and the support of local government as well as RT / RW and communities along the river of Ciliwung have not supported KANCIL activities. This community also has not had adequate resources yet, so they have not been able to work closely with the government of Depok.

Therefore, the main factor discovered is the lack of knowledge against the benefits on keeping the river in the informal community or society. Another factor is the lack of support from formal leader. This study concluded that the bottom-up activities, such as KANCIL, required knowledge and commitment of participants as the pioneers. If the local people do not have adequate knowledge, the role of leader and formal institutions must be strong. Knowledge and support of formal leaders are very important to encourage the people in carrying out the program that has been compiled, so that all levels of society could be involved.

\section{ACKNOWLEDGEMENTS}

This work is supported by Higher Education Science and Technology Development Grant funded by Indonesia Ministry of Research and Higher Education Contract no. 1718/UN2.R12/HKP.05.00/2016.

\section{REFERENCES}

[1] Ci Liwung, https://id.wikipedia.org/wiki/Ci_Liwung. Accessed on: 2 Nov. 2016.

[2] Konservasi DAS Ciliwung. https://konservasidasciliwung.wordpress.com/komunitas/ komunitas-ciliwung-depok/. Accessed on: 2 Nov. 2016.

[3] Blackman. Personal Communication, Lecture of Urban Society and Culture, Universitas Indonesia. Jakarta, Indonesia. Accessed on: 8 Sep. 2016.

[4] Nikmah, S. K., Pengabaian Pemerintah Terhadap Eksistensi Penduduk Pinggir Sungai Ciliwung: Wajah Pengelolaan Sungai di Indonesia. INFID, Jakarta, 2010. 
[5] Demography, http://www.depok.go.id/profil-kota/demografi. Accessed on: 2 Nov. 2016

[6] Bizjak, I., Improving public participation in spatial planning with web 2.0 tools, Urbani Izziv, Retrieved from http://search.proquest.com/docview/1270855319?accountid= 17242. Accessed on: 3 Oct. 2016.

[7] Safrida, Nila, Faktor-faktor yang Mempengaruhi Partisipasi Masyarakat dalam Penataan Ruang Kota. Studi terhadap Penyusunan Rencana Lingkungan RW 08, Kelurahan Jatinegara, Kecamatan Cakung, Jakarta Timur. Universitas Indonesia, Depok, 2007.

[8] Bachri, B.S., Meyakinkan Validitas Data Melalui Triangulasi Pada Penelitian Kualitatif. Universitas Negeri Surabaya, Surabaya, 2016.

[9] Septiady, Yopie. Personal Communication, , Lecture of Urban Society and Culture, Universitas Indonesia. Jakarta, Indonesia. 8 Sep. 2016.

[10] Sumabrata, Jachrizal. Sumadio, Widyawati. et al., Report of Research Resilience City Claster, Publication: Jakarta, 2016. 